\title{
Tsunami risk and impacts on coastlines
}

\author{
Ioan Nistor • Murat Saatcioglu
}

Received: 25 July 2011/Accepted: 25 July 2011/Published online: 25 August 2011

(C) Springer Science+Business Media B.V. 2011

Tsunami waves represent extreme often catastrophic events, which significantly and adversely impact coastal areas. In spite of the lower frequency of occurrence comparing to storms and storm-induced surges, tsunami-induced coastal flooding often leads to massive casualties and tremendous economic losses. Hence, although tsunamis are a rare event, they often come in the form of a high-impact natural disaster. This Special Issue on Tsunami Risk and Impacts on Coastlines comprises ten papers by an international group of authors. The first paper is titled "The earthquakes and related tsunamis of October 6, 1944 and March 7, 1867, NE Aegean Sea" and is written by Altinok et al. The second paper is authored by Alpar et al. and deals with new approaches in the assessment of tsunami deposits in Dalman, SW Turkey. The third paper, by Lopez et al., has the title "Evidence for mid to late Holocene paleotsunami deposits, Kakawis Lake, Vancouver Island, British Columbia." The fourth paper which is on the far field impact and coastal sedimentation associated with the 2006 Java tsunami in West Australia is by Prendergast and Brown. A corrected 3-D SPH method for modeling breaking tsunami waves by Xie et al. is the theme for the fifth paper. The sixth paper by Rajakumari and Subramanian deals with the topic of behaviour of tsunami waves along the coasts of Kancheepuram and Villupuram Districts in Tamil Nadu, India. The post-depositional changes to the onshore 2004 tsunami deposits on the Andaman Sea coast of Thailand are dealt with by Szczucinski in paper seven. Paper eight bears the title "Tsunami vulnerability assessment in urban areas using a numerical model and GIS" and is prepared by Usha et al. The evaluation of Canada tsunami risk and numerical modeling for potential tsunamis along western Canada coast is the focus of the ninth paper by Xie et al. The final paper is written by Murthy et al. and is about mapping of coastal inundation along Nagapattinam based on field observations.

The guest editors would like to express their gratitude to Springer for inviting them to guest-edit this Special Issue, and they hope that this will contribute to the knowledge and understanding of the tsunami risk and the coastal impacts that they generate.

I. Nistor $(\bowtie) \cdot$ M. Saatcioglu

University of Ottawa, Ottawa, ON, Canada

e-mail: inistor@uottawa.ca 